\title{
Uptake of phytodetritus by three ostracod species from the Baltic Sea: effects of amphipod disturbance and ostracod density
}

\author{
Helene Modig ${ }^{1, *}$, Wouter J. van de Bund ${ }^{2, * *}$, Emil Ólafsson ${ }^{1}$ \\ ${ }^{1}$ Department of Zoology, and ${ }^{2}$ Department of Systems Ecology, Stockholm University, 10691 Stockholm, Sweden
}

\begin{abstract}
Three species of ostracods (Candona neglecta, Paracyprideis fennica and Heterocyprideis sorbyana) are common in the Baltic proper and often contribute more to the total meiobenthic biomass than any other taxon. An earlier experiment has shown that C. neglecta assimilates more labelled diatoms (Skeletonema costatum) than any other meiobenthic species, and 10 and 100 times more than the other 2 ostracod species, respectively. The uptake of phytodetritus by the 3 ostracod species was investigated in 2 separate experiments with special reference to (1) effects of the presence of amphipods and (2) variable density of ostracods. The amphipods had negative effects on the uptake rate of phytodetritus by ostracods. Mechanical disturbance, which may have caused burial of the phytodetritus, is one plausible explanation. There was no evidence of competition for phytodetritus among the ostracod species, i.e. the absence/presence of $C$. neglecta did not affect the uptake of phytodetritus by $P$. fennica and $H$. sorbyana. A density-dependent uptake of phytodetritus was, however, observed in C. neglecta, where the uptake of phytodetritus was stimulated at an intermediate density.
\end{abstract}

KEY WORDS: ${ }^{14} \mathrm{C}$ radio-labelled phytodetritus $\cdot$ Ostracoda $\cdot$ Amphipoda $\cdot$ Meiofauna $\cdot$ Disturbance Competition

\section{INTRODUCTION}

Disturbance involves a number of processes that alter the benthic habitat and conditions for the fauna living therein. Animal activities such as burrowing, digging and reworking of the sediment can be defined as 'biotic disturbance', while predation and competition would be 'biotic interactions'. The distinction between these processes is not always clear-cut. For example, a predator can simultaneously have effects through both processes.

\footnotetext{
*E-mail: helene.modig@zoologi.su.se

** Present address: Netherlands Institute of Ecology, Centre for Limnology, Box 1299, 3600 BG Maarssen, The Netherlands
}

Mortality is the most common measurement of biotic disturbance and biotic interactions effects, while sublethal effects, such as reduced growth or reproduction rate, may be more difficult to measure. Sediment disturbance can change meiobenthic species abundance sufficiently to alter community structure (Thistle 1980, Creed \& Coull 1984, Coull \& Palmer 1984 and references therein, Kneib 1985, Palmer 1988, Ólafsson \& Moore 1990, Ólafsson et al. 1990, Warwick et al. 1990, 1997, Ólafsson \& Elmgren 1991, Aarnio et al. 1998, Schratzberger \& Warwick 1998). Meiofauna species and taxa often respond differently to disturbance, which may partly be explained by differences in their vertical distribution. It has been demonstrated that the abundance of epibenthic species can be reduced through direct predation, competition or other physical 
factors, while species dwelling in deeper sediment layers can be promoted after a disturbance event possibly due to enhanced food resources or improved chemical conditions in these layers (Ólafsson \& Elmgren 1991). However, epibenthic species can also increase in abundance after both physical (Alongi 1985) and biotic (Ólafsson \& Elmgren 1991) sediment disturbance events.

There is overwhelming evidence for both intra- and interspecific competition for food in soft-bottom communities (see for review Wilson 1991, Ólafsson et al. 1994). There are, however, few studies on competition for food between meio- and macrofauna or between taxa or species within meiofauna. There are indications of food competition between meiofauna and macrofauna inferred from microcosm experiments (Alongi \& Tenore 1985, Ólafsson et al. 1993), but evidence is still circumstantial.

The soft-bottom meiobenthic community in the Baltic proper is relatively simple compared with more saline areas. Most of the species are deposit feeders, with nematodes being the most abundant taxon comprising 40 to 50 species. Harpacticoids and ostracods, the second and third most abundant taxa, are dominated by 2 and 3 species respectively. Turbellarians, kinorhynchs and oligochaetes represent the less numerous taxa in the community (Ólafsson \& Elmgren 1997). Ostracods often contribute more to the total meiobenthic biomass than any other taxon (Ólafsson \& Elmgren 1997) and can be among the most important taxa after long-term hypoxia because of their tolerance for low oxygen concentrations (Modig \& Ólafsson 1998).

Ólafsson et al. (1999) studied the uptake of labelled phytodetritus within a meiobenthic community from the northern Baltic proper. There was substantial variation in the uptake of labelled material even among species within the same class or phylum. Both total uptake and uptake per unit biomass of ${ }^{14} \mathrm{C}$ were by far highest in the ostracod Candona neglecta (Sars), accounting for $46 \%$ of the total meiofauna uptake. The uptake of labelled material was significantly different among all 3 common ostracod species, C. neglecta taking 10 and 100 times more than Paracyprideis fennica (Hirschmann) and Heterocyprideis sorbyana (Jones), respectively.

Paracyprideis fennica and Heterocyprideis sorbyana are both considered to be glacial relicts in the Baltic Sea (Järvekülg 1973) and their size frequency distributions indicate generation times of at least 2 yr (Ankar \& Elmgren 1976). P. fennica is endemic in the Baltic and its northern distribution limits are found in the Bothnian Sea (Elofsson 1941). H. sorbyana was previously known as a typical arctic species but its recent discovery in Antarctica showed it to have a bipolar distribu- tion (Hartman 1994). Candona neglecta is widely distributed throughout Europe and North Africa in freshwater habitats such as ponds, lakes marshes, ditches and even caves (Henderson 1990). It has 2 generations $\mathrm{yr}^{-1}$ in Swedish lakes (Alm 1915), and Savolainen \& Valtonen (1983) showed that it takes 4 mo for $C$. neglecta to reach adult stage in Bothnian Bay.

The amphipods Monoporeia affinis (Lindstöm) and Pontoporeia femorata Krøyer, coexist in the deepmuddy soft-bottoms in the Baltic proper where they contribute substantially to macrofaunal abundance and biomass (Elmgren 1978). Both species are deposit feeders that assimilate and store food resources from the diatom bloom (Hill et al. 1992). Both are found in the top $5 \mathrm{~cm}$ of the sediment, though $P$. femorata can be found deeper (Hill \& Elmgren 1987). In addition, M. affinis swims more actively and feeds more rapidly than P. femorata (Lopez \& Elmgren 1989).

Amphipods and ostracods co-occur in sediments of the Baltic proper. Both are deposit feeders and so competition for food resources is plausible if food is a limiting factor. Amphipods also may crush the shells of ostracods while feeding, as they seem to do with Macoma balthica spat (Elmgren et al. 1986, Ejdung \& Elmgren 1998). Disturbance of the sediment by the amphipods may also affect food availability for ostracods.

The aim of the present study was to investigate the effects of amphipod species (Monoporeia affinis and Pontoporeia femorata) on the uptake of phytodetritus by 3 species of ostracods, Paracyprideis fennica, Heterocyprideis sorbyana and Candona neglecta. Our expectations were that the amphipods would generate different disturbance effects on the ostracods due to differences in their feeding rates and burrowing depths.

We also tested for intra- and interspecific competition among ostracod species. If there was competition for phytodetritus among ostracods, we expected that removal of the species with the highest consumption rate (Candona neglecta) would result in an increased uptake by the other species. Also we expected that there would be density-dependent factors controlling the uptake by individual species.

\section{MATERIAL AND METHODS}

Culturing and labelling algae. The diatom Skeletonema costatum was cultured at $15^{\circ} \mathrm{C}$ in 15 psu artificial seawater (Kester et al. 1967) with added nutrients

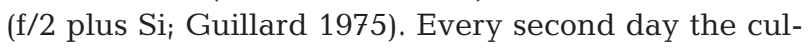
tures were shaken manually. Algae were labelled by adding $0.34 \mathrm{mCi} \mathrm{NaH}^{14} \mathrm{CO}_{3}$ (Amersham; specific activity $54.0 \mathrm{mCi} \mathrm{mmol}^{-1}$ ) to each culture flask $4 \mathrm{~d}$ after starting the culture. After 7 more days of incubation, 
the labelled algae were harvested by allowing them to settle for $5 \mathrm{~h}$ at $4^{\circ} \mathrm{C}$ in the dark in a separatory funnel. The labelled algae were washed by re-suspending them in clean medium and allowing them to settle again; this procedure was repeated twice. In Expt 1 the final radioactivity in the diatoms was $0.38 \mathrm{mCi} \mathrm{g}^{-1}$ dry wt and in Expt 2 it was $0.23 \mathrm{mCi} \mathrm{g}^{-1}$ dry wt. We refer to the fresh phytoplankton-derived detritus as phytodetritus throughout the text.

Expt 1. Expt 1 was designed to investigate the effects of amphipods on the uptake of phytodetritus by 3 ostracod species. Sediment sampling took place in early April 1996 at a depth of 30 to $40 \mathrm{~m}$ in the northwestern Baltic Proper $\left(58^{\circ} 49^{\prime} \mathrm{N}, 17^{\circ} 38^{\prime} \mathrm{E}\right)$. Surficial sediment (the upper $2 \mathrm{~cm}$ ) was collected using an epibenthic sled (Blomqvist \& Lundgren 1996). The sediment was sieved through a $500 \mu \mathrm{m}$ mesh to remove macrofauna. Prior to the initiation of the experiment, the sieved sediment was stored for $6 \mathrm{wk}$ under aerated brackish water in a dark thermoconstant room at $4^{\circ} \mathrm{C}$. Amphipods were collected with an epibenthic sled at the same site in late April just before the onset of the spring bloom, and 1 yr old individuals (about $7 \mathrm{~mm}$ ) of both species were picked out. The animals were kept in an aquarium with sieved $(<500 \mu \mathrm{m})$ sediment covered with aerated brackish water under the same conditions as described above during ca 3 wk until the start of the experiment.

Erlenmeyer flasks $(500 \mathrm{ml})$ with a bottom surface area of $78.5 \mathrm{~cm}^{2}$ were used as microcosms. Three weeks before the addition of the labelled algae, $75 \mathrm{~g}$ of sieved sediment (wet wt) was added to each microcosm, forming a bottom layer of ca $2 \mathrm{~cm}$. The microcosms were filled up with brackish water (salinity $7 \mathrm{psu}$ ), and each microcosm was connected to a $1500 \mathrm{ml}$ water reservoir. The microcosms were at all times incubated in the dark at a temperature of $4^{\circ} \mathrm{C}$. Peristaltic pumps were connected to the reservoirs and switched on after $24 \mathrm{~h}$ upon addition of the sediment to the flasks. The water phase in the microcosms was completely turned over every $7.8 \mathrm{~h}$, and the reservoirs were continuously aerated. The outgoing air was flushed through tubes filled with $25 \mathrm{ml}$ Carbo-Sorb E (Packard) to capture the $\mathrm{CO}_{2}$ (Fig. 1). Amphipods were added to microcosms $4 \mathrm{~d}$ after the pumps were switched on. Thirty-nine microcosms were used allowing 10 different treatments (Table 1). S: sieved sediment (without amphipods and no mechanical disturbance), M: Monoporeia affinis at a density of 640 ind. $\mathrm{m}^{-2}$ (5 ind. microcosm $\left.{ }^{-1}\right), \mathrm{MH}: M$. affinis at densities of 1280 ind. $\mathrm{m}^{-2}$ (10 ind. microcosm ${ }^{-1}$ ) and 2560 ind. $\mathrm{m}^{-2}$ (20 ind. microcosm ${ }^{-1}$ ), P: Pontoporeia femorata at a density of 640 ind. $\mathrm{m}^{-2}$ (5 ind. microcosm ${ }^{-1}$ ), MP: $M$. affinis and $P$. femorata together at a total density of 1280 ind. $\mathrm{m}^{-2}$ (5 ind. of each species per microcosm) and ST: mechanically stirred sediment. In the ST microcosms a $2.5 \mathrm{~cm}$ long magnet was buried in the sediment and 3 times a week the sediment was disturbed by switching the stirring motor on and off very briefly (less than $0.5 \mathrm{~s}$ ). Two microcosms (F in Table 1) served as formaldehyde blinds and were fixed with $4 \%$ formaldehyde $2 \mathrm{~d}$ before addition of the labelled diatoms. The experiment was run for 1 mo for all treatments except two: the SL: sieved sediment (without amphipods and no mechanical disturbance) and the ML: $M$. affinis at a density of 640 ind. $\mathrm{m}^{-2}$ (5 ind. micro$\left.\operatorname{cosm}^{-1}\right)$, treatments, which were run for 3 mo. Amphipod densities used in the experiment are within the range found in nature.

Originally, the experimental design consisted of 54 microcosms but during the first days of the experiment 1 of the 4 peristaltic pump units broke down resulting in temporary hypoxia and subsequent amphipod mortality in 15 of the microcosms. The reported results are from the 39 unaffected microcosms; as a result of this, the division of replicates over the treatments is slightly

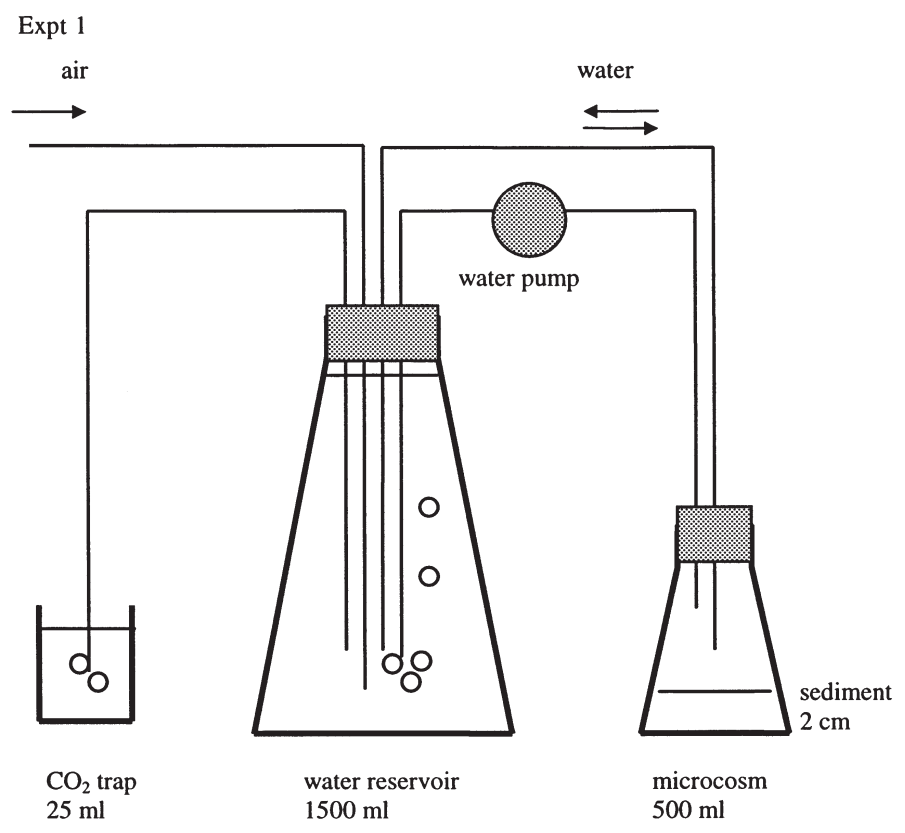

Expt 2

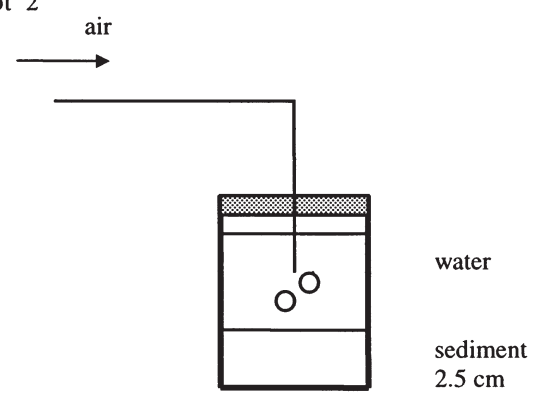

Fig. 1. Schematic illustration of the experimental set-up 
Table 1. The experimental set-up, with the number of the 2 amphipod species Monoporeia affinis and Pontoporeia femorata in different treatments. The number of replicates and incubation time are also presented. Treatment descriptions are given in 'Material and methods: Expt 1'

\begin{tabular}{|c|c|c|c|c|}
\hline Treatment & $\begin{array}{l}\text { No. of } \\
\text { M. affinis }\end{array}$ & $\begin{array}{c}\text { No. of } \\
\text { P. femorata }\end{array}$ & $\begin{array}{l}\text { No. of } \\
\text { replicates }\end{array}$ & $\begin{array}{c}\text { Incubation } \\
\text { time (mo) }\end{array}$ \\
\hline Sieved sediment $(\mathrm{S})$ & 0 & 0 & 5 & 1 \\
\hline Sieved sediment (SL) & 0 & 0 & 4 & 3 \\
\hline M. affinis (M) & 5 & 0 & 6 & 1 \\
\hline M. affinis (ML) & 5 & 0 & 4 & 3 \\
\hline M. affinis $(\mathrm{MH})$ & 10 & 0 & 2 & 1 \\
\hline M. affinis $(\mathrm{MH})$ & 20 & 0 & 2 & 1 \\
\hline P. femorata $(\mathrm{P})$ & 0 & 5 & 4 & 1 \\
\hline M. affinis $+P$. femorata (MP) & 5 & 5 & 6 & 1 \\
\hline Artificial disturbance (ST) & 0 & 0 & 4 & 1 \\
\hline Formaldehyde-killed sieved blinds (F) & 0 & 0 & 2 & 1 \\
\hline
\end{tabular}

unbalanced. Especially the 2 treatments with high $M$. affinis densities (M10 and M20) were affected. The 2 replicates of each $\mathrm{M} 10$ and $\mathrm{M} 20$ were pooled into 1 treatment in the statistical test to ensure sufficient replicates.

We added $3 \mathrm{ml}$ of diatom suspension containing $46.8 \mathrm{mg}$ dry wt and a total activity of $2.8 \times 10^{7} \mathrm{dpm}$ (disintegrations per minute) to each microcosm with a Pasteur pipette. This corresponds to ca $7 \mathrm{~d}$ of sedimentation during a typical spring bloom in the field (Blomqvist \& Larsson 1994). The $\mathrm{CO}_{2}$ traps were connected immediately after the addition of labelled diatoms.

The experimental units were disconnected after 1 or 3 mo. The water was removed and the sediment in the microcosms containing amphipods was sieved through a sieve of $500 \mu \mathrm{m}$ mesh size. The rest of the sediment was fixed with $4 \%$ formaldehyde. Samples were taken from the water, sediment, ostracods and amphipods for analysis of radioactivity.

Expt 2. Expt 2 was designed to test whether there are density-dependent factors controlling the uptake of phytodetritus both within and among species. Sediment was collected in mid-March 1997, before the onset of the spring bloom, at the same site as before. The sediment was sieved through a $500 \mu \mathrm{m}$ sieve to remove macrofauna and then through a $200 \mu \mathrm{m}$ sieve to remove large meiofauna (including adult ostracods).

Sieved sediment was placed in $180 \mathrm{ml}$ plastic jars (internal diameter of $5.3 \mathrm{~cm}$ and $6.8 \mathrm{~cm}$ height). Microcosms were kept in a dark thermoconstant room at 4 to $5^{\circ} \mathrm{C}$, sealed with a plastic lid, aerated with air stones and the salinity was kept within the range of 6.6 to $7.0 \mathrm{psu}$ (Fig. 1). The microcosms were left to stabilize for ca 2 mo. Ostracods were collected at the beginning of May from the same area where the sediment was collected. A total of 45 microcosms was used to permit 9 treatments of 5 replicates each (Table 2). Treatment 1 : sieved sediment (without ostracods), 2: Candona neglecta (5 ind. microcosm ${ }^{-1}$ ), 3: C. neglecta (10 ind. microcosm ${ }^{-1}$ ), 4: Paracyprideis fennica (40 ind. micro$\operatorname{cosm}^{-1}$ ), 5: Heterocyprideis sorbyana (40 ind. micro$\left.\operatorname{cosm}^{-1}\right)$, 6: P. fennica, $H$. sorbyana and $C$. neglecta together $(40 \mathrm{P}$. fennica, $40 \mathrm{H}$. sorbyana and $20 \mathrm{C}$. neglecta, together 100 ind. microcosm ${ }^{-1}$ ), 7: P. fennica and $H$. sorbyana together (40 ind. of each species per microcosm), 8: P. fennica and $H$. sorbyana together (20 $P$. fennica and $60 \mathrm{H}$. sorbyana, together 80 ind. micro$\operatorname{cosm}^{-1}$ ), 9: P. fennica (20 ind. microcosm ${ }^{-1}$ ).

At the start of the experiment the water was exchanged in all microcosms, animals were placed in the microcosms and then $0.11 \mathrm{ml}$ of labelled diatom suspension containing $3 \mathrm{mg}$ dry wt and a total activity of $2.8 \times 10^{6} \mathrm{dpm}$ was added to each microcosm. The carbon added corresponded to $1 / 10$ of the carbon added in Expt 1. The incubation ran for a total of $2 \mathrm{wk}$ and after $1 \mathrm{wk}$ about $6 \mathrm{ml}$ of the water was exchanged in each microcosm. The oxygen concentration in the

Table 2. Three ostracod species, Paracyprideis fennica, Heterocyprideis sorbyana and Candona neglecta, were assigned to 9 treatments, each treatment of 5 replicates. Treatment 1 served as blank (without ostracods). Treatment descriptions are given in 'Material and methods: Expt 2'

\begin{tabular}{|lccc|}
\hline Treatment & $\begin{array}{c}\text { No. of } \\
\text { P. fennica }\end{array}$ & $\begin{array}{c}\text { No. of } \\
\text { H. sorbyana }\end{array}$ & $\begin{array}{c}\text { No. of } \\
\text { C. neglecta }\end{array}$ \\
\hline 1 & 0 & 0 & 0 \\
2 & 0 & 0 & 5 \\
3 & 0 & 0 & 10 \\
4 & 40 & 0 & 0 \\
5 & 0 & 40 & 0 \\
6 & 40 & 40 & 20 \\
7 & 40 & 40 & 0 \\
8 & 20 & 60 & 0 \\
9 & 20 & 0 & 0 \\
\hline
\end{tabular}


water column was regularly controlled, and never fell below $70 \%$. At the end of the experiment the sediment was fixed in $4 \%$ formaldehyde.

Measuring radioactivity (both experiments). All radioactivity samples were counted with a LKB scintillation counter using a standard ${ }^{14} \mathrm{C}$ counting program. Quenching was corrected for each sample by measuring a quenching parameter (SQP(E)) using an external standard, and calculating counting efficiency from a calibration curve obtained from quenched standard samples.

Respiration measurements (Expt 1). The radioactivity in the $\mathrm{CO}_{2}$ traps was measured after 7, 9, 23 and $29 \mathrm{~d}$ (all microcosms), and also after 2 and 3 mo (long incubation microcosms only). This was done by taking a $1 \mathrm{ml}$ sample from the traps, adding $10 \mathrm{ml}$ scintillation liquid (PermaFluor E+, Packard) and counting in a liquid scintillation counter (see below). The $\mathrm{CO}_{2}$ traps were replaced after each sampling, and at the same time two $1 \mathrm{ml}$ water samples were taken from each water reservoir. To one of these samples $1 \mathrm{ml}$ CarboSorb was added to fix $\mathrm{CO}_{2}$, to the other $1 \mathrm{ml} 1 \mathrm{~N} \mathrm{HCl}$ was added to release $\mathrm{CO}_{2}$. Water samples were counted in $10 \mathrm{ml}$ Hionic-Fluor (Packard). Dissolved ${ }^{14} \mathrm{CO}_{2}$ in the water was calculated from the activity in samples with fixed and released $\mathrm{CO}_{2}$. Total released ${ }^{14} \mathrm{CO}_{2}$ was calculated from activity in the traps and dissolved ${ }^{14} \mathrm{CO}_{2}$.

Sediment and animal analysis (both experiments). A small sediment sample was freeze-dried and solubilized overnight at $50^{\circ} \mathrm{C}$ in $80 \%$ Soluene-350 (Packard). Ten ml Hionic-Fluor (Packard) was added and the samples were shaken, incubated in the dark overnight and radioactivity was measured. The sediment containing amphipods (Expt 1) was first sieved through a $500 \mu \mathrm{m}$ sieve to remove amphipods. The rest of the sediment was sieved through a $200 \mu \mathrm{m}$ sieve and all ostracods were picked out. In all other microcosms without amphipods (both experiments) the sediment was directly sieved through a $200 \mu \mathrm{m}$ sieve before picking out the ostracods. The length of the ostracods was measured and individuals of the same species with similar size were grouped together in vials (maximum 11 individuals in each vial). The adult Candona neglecta were placed individually in each vial. All animals were dried overnight at $60^{\circ} \mathrm{C}$ and then solubilized overnight at $50^{\circ} \mathrm{C}$ in $80 \%$ Soluene-350. Ten ml was added and the samples were shaken, incubated in the dark overnight and radioactivity measurements performed as described above. Ostracod biomass was estimated from a size-weight relationship (see Ólafsson \& Elmgren 1997). The specific uptake rate for each species was obtained from each replicate by taking an average value of weight and uptake.

Statistics. One-way ANOVA was used to compare the uptake $\left(\mathrm{dpm} \mu \mathrm{g}^{-1}\right)$ of labelled material among treatments for the 3 ostracod species, the no. of ostracods in the different treatments and the amount of labelled material in the sediment. Paired a posteriori comparisons were carried out with the Tukey test using $95 \%$ confidence limits. Prior to the analysis of variance, Cochran's $C$-test was used to check the assumption of homoscedasticity. In cases of unequal variances, data were $\log _{10}(x+1)$ transformed prior to the ANOVA. All transformations resulted in homogeneity of the variance. In order to investigate a correlation between ostracod number and uptake of

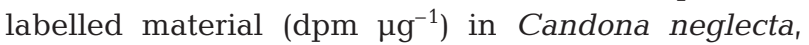
Spearman rank order correlation was used.

\section{RESULTS}

\section{Expt 1}

Around $80 \%$ of the labelled diatom ${ }^{14} \mathrm{C}$ (sediment ${ }^{14} \mathrm{C}_{\text {, }}{ }^{14} \mathrm{CO}_{2}$, $\mathrm{DO}^{14} \mathrm{C}$ and ${ }^{14} \mathrm{C}$ in animal tissue) was recovered in the measured fractions. Of the recovered labelled material 51 to $77 \%$ was found in the sediment after 1 mo and 49 to $66 \%$ after 3 mo. Released ${ }^{14} \mathrm{CO}_{2}$ was on average $24 \%$ after $1 \mathrm{mo}$ and $35 \%$ after $3 \mathrm{mo}$; dissolved organic ${ }^{14} \mathrm{C}$ was on average $6 \%$ in both 1 and 3 mo incubations. The uptake of labelled carbon in ostracods was 0.01 and $0.03 \%$ of total recovered carbon after 1 and $3 \mathrm{mo}$, respectively. 1 to $11 \%$ of the measured activity was found in the amphipods when they were present. The recovery in the formaldehyde blinds was $83 \%$, where $1.5 \%$ was measured as ${ }^{14} \mathrm{CO}_{2}$, $6.5 \%$ as $\mathrm{DO}^{14} \mathrm{C}$ and the remaining $92 \%$ as sediment ${ }^{14} \mathrm{C}$. The activity measured in ostracods in formaldehyde blinds was very low, ranging from 0.14 to

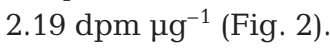

\section{One month incubation}

On average, $12.3 \pm 0.6$ (SE) ostracods were found in each microcosm, $6.2 \pm 0.5$ (SE) for Paracyprideis fennica, $5.5 \pm 0.4$ (SE) for Candona neglecta and $0.6 \pm 0.1$ (SE) for Heterocyprideis sorbyana.

Numbers of surviving ostracods were not different among the treatments (ANOVA, p > 0.05), but there was a significant difference among treatments in the uptake of phytodetritus by ostracods (ANOVA, p < 0.05). A significantly higher amount of phytodetritus was taken up by the ostracods in microcosms with only sieved sediment (S) compared with treatments P (Pontoporeia femorata), MP (Monoporeia affinis and $P$. femorata together), $\mathrm{MH}$ ( $M$. affinis, high density), and stirred sediment (ST) (ANOVA, $\mathrm{p}<0.05$, Tukey test). There was also a large difference among ostracod 

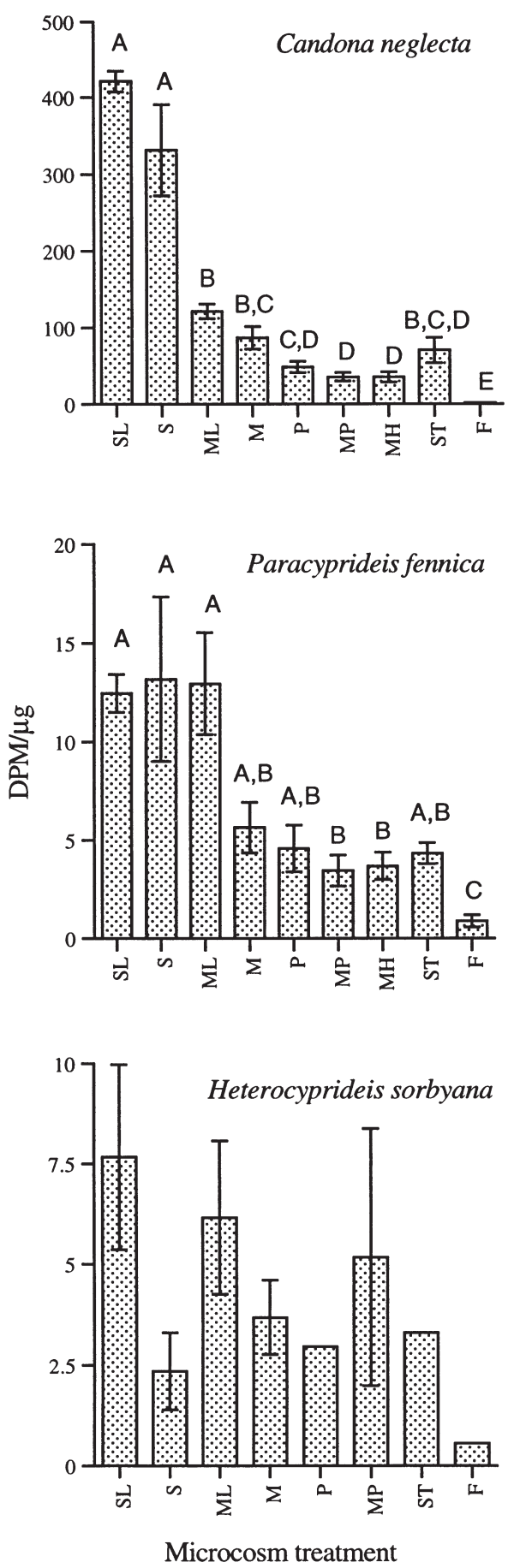

Fig. 2. Average ${ }^{14} \mathrm{C}$ uptake $\left(\mathrm{dpm} \mu \mathrm{g}^{-1}\right)$ by the 3 ostracod species in different treatments in Expt 1. Microcosm treatments were SL, S (sediment without amphipods), ML, M (Monoporeia affinis), $\mathrm{P}$ (Pontoporeia femorata), MP (M. affinis $+P$. femorata), MH (M. affinis, high density), ST (artificial disturbance) and F (formaldehyde blinds - control). In treatments P, ST and F, few Heterocyprideis sorbyana were found and only one ${ }^{14} \mathrm{C}$ measurement carried out. SL and ML were incubated for 3 mo while all other microcosms were incubated for 1 mo. Error bars represent standard errors. Common letters above bars indicate no significant difference (Tukey test) species in their uptake of phytodetritus (Fig. 2). Candona neglecta incorporated $92 \%$ of the measured activity in ostracods, Paracyprideis fennica 8\% and Heterocyprideis sorbyana less than $1 \%$.

\section{Three month incubation}

The number of ostracods did not differ within the 3 mo treatment nor between the 3 and 1 mo treatments (ANOVA, p > 0.05). There was a significant difference between treatments in the ostracod uptake of ${ }^{14} \mathrm{C}$, with more phytodetritus taken up in microcosms with only sieved sediment SL (sediment only) compared with ML (Monoporeia affinis present) (ANOVA, p < 0.05). Candona neglecta was responsible for $93 \%$ of the total ostracod uptake, Paracyprideis fennica $6 \%$ and Heterocyprideis sorbyana less than $1 \%$.

\section{Specific uptake of labelled material by ostracod species}

\section{Candona neglecta}

On average, the specific uptake varied from 35.3 to $421.3 \mathrm{dpm} \mathrm{ug}^{-1}$ dry wt (Fig. 2). The incorporation of phytodetritus differed among the treatments, with a much larger uptake in the undisturbed treatments (SL and $\mathrm{S}$ ) than in the disturbed treatments (ML, M, P, MH and ST) (Fig 2; ANOVA, p $<0.001$, Tukey test). The uptake of phytodetritus was also higher in M microcosms (Monoporeia affinis) compared with treatments MP (M. affinis and Pontoporeia femorata) and $\mathrm{MH}(M$. affinis high density)(ANOVA, $\mathrm{p}<0.05$, Tukey test). In ML microcosms ( $M$. affinis incubated $3 \mathrm{mo}$ ) more phytodetritus was incorporated in C. neglecta compared with $\mathrm{P}$ ( $P$. femorata), $\mathrm{MP}$ and $\mathrm{MH}$ microcosms (ANOVA, $\mathrm{p}<0.01$, Tukey test).

\section{Paracyprideis fennica}

The average activity in $P$. fennica was 3.4 to $13.2 \mathrm{dpm} \mu \mathrm{g}^{-1}$ dry wt (Fig. 2). The incorporation of phytodetritus was higher in treatments SL, S and ML compared with MP and MH treatments (Fig. 2; ANOVA, $\mathrm{p}<0.05$, Tukey test).

\section{Heterocyprideis sorbyana}

The average activity in $H$. sorbyana was 2.3 to $7.7 \mathrm{dpm} \mu \mathrm{g}^{-1}$ dry wt and $0.6 \mathrm{dpm} \mu \mathrm{g}^{-1}$ in formaldehyde blinds (Fig. 2). H. sorbyana was found only in 1 of the 
2 formaldehyde blind microcosms and therefore it was excluded from the ANOVA test. No difference was found among the other treatments in the uptake of phytodetritus by $H$. sorbyana (Fig. 2; ANOVA, p > 0.05).

\section{Expt 2}

On average $46 \%$ (36 to $61 \%$ ) of the added label was found in the sediment after $2 \mathrm{wk}$. There was no significant difference among the different treatments in the recovery from the sediment $(p>0.05)$. Of the total added label to the microcosms, $0.1 \%$ of the activity was measured in ostracods.

\section{Uptake of labelled material in ostracod species}

As in Expt 1, the uptake of phytodetritus was higher in Candona neglecta compared with the other 2 species. C. neglecta took up on average 28.7 to $57.5 \mathrm{dpm}$ $\mu^{-1}$ dry wt, while the specific activity in Paracyprideis

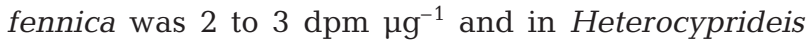

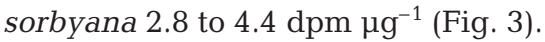

\section{Candona neglecta}

Biomass-specific incorporation of phytodetritus differed among treatments. In microcosms with 10 Candona neglecta (Treatment 3 ) the activity per $\mu \mathrm{g}$ was ca 2 times higher than in microcosms with 5 individuals (Treatment 2) (Fig. 3; ANOVA, p $<0.05$ Tukey test). The activity per $\mu \mathrm{g}$ was also higher in Treatment 3 compared with Treatment 6 where C. neglecta was placed together with the 2 other species (ANOVA, p < 0.01 Tukey test). There was no significant correlation between the dpm $\mu^{-1}$ in C. neglecta and the number of ostracods present in the microcosms (Spearman rank order correlation $\mathrm{p}>0.05$ ).

\section{Paracyprideis fennica and Heterocyprideis sorbyana}

There was no significant difference in uptake in $P$. fennica and $H$. sorbyana in the different treatments $(\mathrm{p}>0.05)$.

\section{DISCUSSION}

Both the artificial and biological (amphipods) disturbance resulted in a lower uptake of phytodetritus by Candona neglecta. This indicates that disturbance of
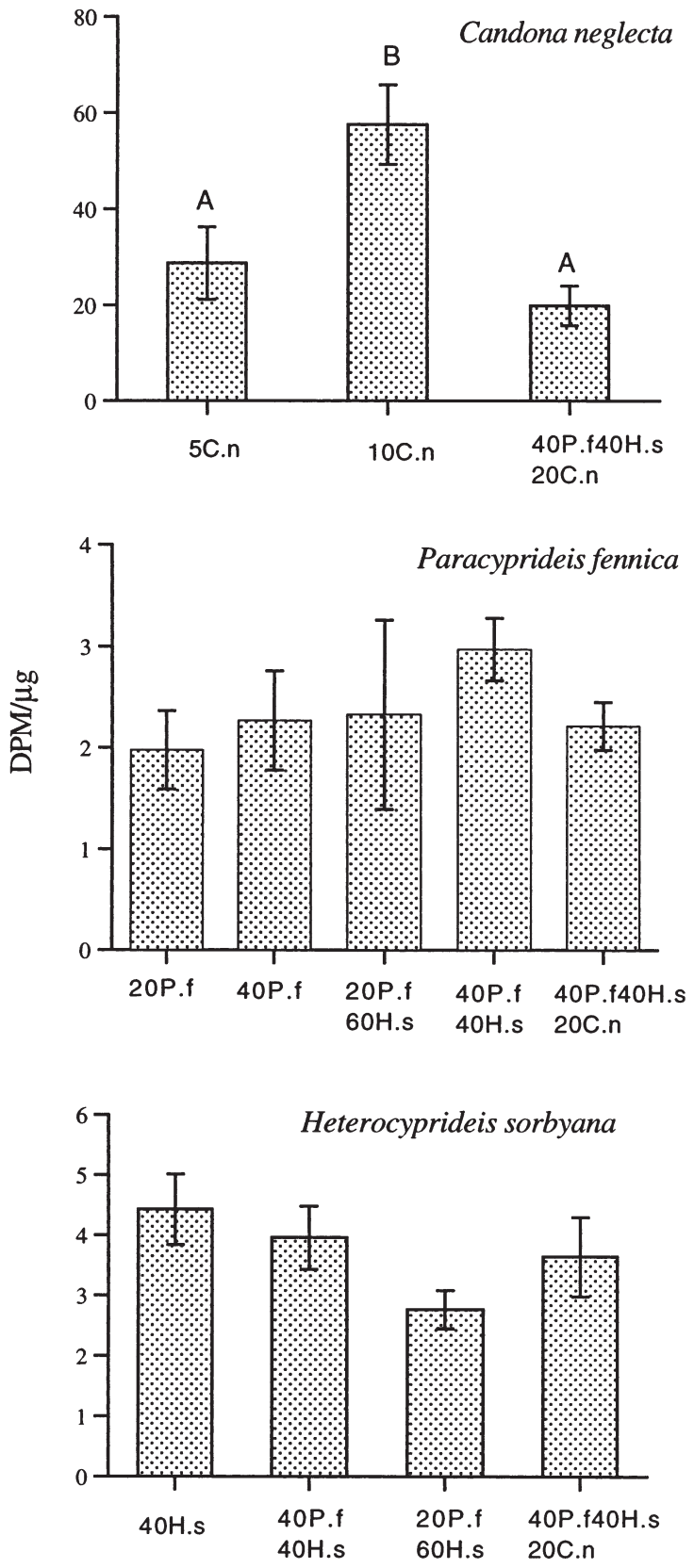

Microcosm treatment

Fig. 3. Average ${ }^{14} \mathrm{C}$ uptake $\left(\mathrm{dpm} \mu \mathrm{g}^{-1}\right)$ by the 3 ostracod species in different treatments in Expt 2. The number and letter codes on the $x$-axes indicate the number of each ostracod species added in each treatment C.n: Candona neglecta, P.f: Paracyprideis fennica and H.s: Heterocyprideis sorbyana. Error bars represent standard errors. Common letters above bars indicate no significant difference (Tukey test)

the sediment played an important role in the reduced uptake by C. neglecta. Alongi \& Tenore (1985) showed that the disturbance generated by one organism may indirectly have a negative effect on another organism 
due to the burial of the food resource. The various ways that benthic organisms may interact are often confounding and rarely separately identified. For example, an epi-benthic predator may also cause a disturbance-induced mortality (Kneib 1985, Palmer 1988).

Amphipods have been shown to have a negative effect on the spat of Macoma balthica as they crush the shell and possibly ingest the remains (Elmgren et al. 1986). Ostracods of similar size and shape might also be crushed and ingested by the amphipods. Sundelin \& Elmgren (1991) showed a negative effect on ostracod abundance in the presence of amphipods. In our study there was no difference in abundance of ostracods between the microcosms with and without amphipods. Perhaps behavioural changes associated with avoiding predation by amphipods inhibited consumption of phytodetritus by the ostracods. This was, however, contradicted by the evidence of a lower uptake with mechanical disturbance only. This disturbance took place 3 times a week, and therefore was unlikely to induce any behavioural changes in the ostracods. One likely explanation for the reduced uptake by ostracods in amphipod treatments is burial of the phytodetritus into the sediment, which would make the food less available for the ostracods. However, since we did not investigate the vertical distribution of the labelled material we cannot prove this. We did not find any differences in disturbance effects generated by the 2 amphipod species, but both of them reduced the uptake by Candona neglecta at the same level.

There are large interspecific differences in the uptake of fresh phytoplankton material among ostracod species from soft bottoms in the Baltic Sea, with Candona neglecta taking up far more than Paracyprideis fennica and Heterocyprideis sorbyana (Ólafsson et al. 1999, this study). Ólafsson et al. (1999) hypothesized that this could be explained by vertical segregation in the sediment or resource partitioning. The 3 ostracod species are confined to the top cm (Ólafsson \& Elmgren 1991, 1997, Ólafsson et al. 1999), but they may have different vertical distribution within this sediment layer. Meiofauna can be vertically segregated on a mm scale in the sediment (Joint et al. 1982, Warwick \& Gee 1984, Fleeger et al. 1995). If $P$. fennica and $H$. sorbyana have a deeper distribution than C. neglecta, one would expect a relatively higher uptake in those 2 species when the sediment surface is disturbed since the freshly deposited material would then become more available to them. However, this did not occur in the present study. Instead, the sediment disturbance had a negative effect on $P$. fennica. Perhaps the simplest explanation is that the 3 ostracod species differ in food preferences. The 3 species might depend on new or old material depending on their life-history characteristics. C. neglecta can complete a life cycle in
4 mo (Savolainen \& Valtonen 1983), whereas the 2 other species have a longer generation time-2 yr according to Ankar \& Elmgren (1976). The seasonal dynamics of the 3 ostracod species from the same area also indicate differences in life cycles. $P$. fennica and $H$. sorbyana peaked in abundance in June while $C$. neglecta had a more even distribution over the year (Ólafsson \& Elmgren 1997). With a shorter life span, growth and reproduction have to be completed on a relatively short time scale and therefore high quality food, as freshly deposited diatoms, may be an important food resource. Ostracods with a longer life cycle might depend on a more reliable and stable food resource, such as old organic material. Possibly, $C$. neglecta is able to quickly increase its feeding rate in response to a diatom pulse, while the other species always feed slowly, and therefore do not benefit from the spring bloom material. Even though Skeletonema costatum is one of the dominant species during spring blooms in the Baltic Sea (Kononen et al. 1992, Heiskanen \& Kononen 1994) other phytoplankton species might also play an important role as food for $P$. fennica and $H$. sorbyana.

At natural field densities, the uptake of labelled phytodetritus by Paracyprideis fennica and Heterocyprideis sorbyana has been found to be much lower than by Candona neglecta (Ólafsson et al. 1999). One might suspect that $C$. neglecta suppress the uptake by the other 2 species through direct interference or competition. However, in Expt 2 here, the uptake of phytodetritus by $P$. fennica and $H$. sorbyana was always low, i.e. in absence of $C$. neglecta the uptake of the 2 other species did not increase. Neither did the density of ostracods nor species combination affect the uptake by $P$. fennica and $H$. sorbyana. Due to uneven densities in most of the treatments, the comparison of phytodetritus uptake by individual ostracod species was difficult to make. Still, the uptake by the 2 ostracod species, $P$. fennica and $H$. sorbyana was consistently low in all microcosms. We conclude that the overall low uptake rates of phytodetritus by $P$. fennica and $H$. sorbyana were due to factors other than food competition or species interactions; low feeding rates and selection for other food resource are likely explanations. We could, however, show that intraspecific interactions significantly affected the uptake of phytodetritus by $C$. neglecta. Interestingly, the uptake by $C$. neglecta was higher in the medium density microcosms compared with low density microcosms. It seems that the uptake of phytodetritus was stimulated to a certain extent by the presence of individuals of the same species ( $C$. neglecta). Higher density of $C$. neglecta might have stimulated its feeding rate resulting in a higher specific uptake of the phytodetritus. Further, if the distribution of the labelled material in the microcosms was patchy, 
the higher density of $C$. neglecta might have been an advantage in order to locate the food patches. It is known that different benthic grazing snail species may differ in their ability to locate food patches. An 'extensive grazer' searches a larger area per unit of time, while the 'intensive grazer' is cropping closer to the substratum -2 different trade-offs which might have evolved to promote competitive coexistence of the snails (Schmitt 1996). If C. neglecta has an 'extensive' feeding behavior, it is likely that the location and uptake of phytodetritus would be promoted by a higher density of the same species up to a certain level.

The reduced uptake within Candona neglecta in the high density microcosms may have several explanations. Firstly, a direct interference with the other 2 ostracod species might have taken place. There is, however, no evidence in our results that support this hypothesis since the uptake of labelled material by Heterocyprideis sorbyana and Paracyprideis fennica did not change in the different treatments. Nevertheless, if $H$. sorbyana and $P$. fennica have a slow feeding rate and mainly depend on old organic matter, it would be difficult to detect if interference among the species had taken place by looking at the uptake of labelled diatoms. Secondly, the high ostracod activity in the high density microcosms might have caused burial of the phytodetritus. Not only macrofauna, but also meiofaunal activity, may play an important role in changing the sediment structure (Cullen 1973, Nehring et al. 1990), thereby enhancing the mineralization of organic carbon (Alkemade et al. 1992) and altering nutrient fluxes (Aller \& Aller 1992). The large amount of labelled material measured in the sediment at the termination of the experiment might have been buried into the deeper sediment layers, and if C. neglecta ingest food mainly from the sediment surface the phytodetritus might not have been an available food source. If the phytodetritus was available to $C$. neglecta only at the sediment surface, intraspecific competition may also be an explanation to the lower uptake in high density microcosms in Expt 2. Unfortunately, it is not possible to draw any such conclusions from this experiment since in the high density treatment all 3 species were present and the effect of intraand interspecific interactions could not be separated.

In conclusion, the most plausible explanation for the negative effects of amphipods on the uptake of phytodetritus by ostracods is sediment disturbance and subsequent burial of the organic material. There was no evidence of competition for phytodetritus among the ostracod species, i.e. the absence/presence of Candona neglecta did not affect the uptake of phytodetritus by Paracyprideis fennica and Heterocyprideis sorbyana, but they assimilated very little of the phytodetritus species in all treatments. $P$. fennica and $H$. sorbyana might have a lower feeding rate than $C$. neglecta and/or depend on another food source, for example, old organic material. A density-dependent uptake of phytodetritus was, however, observed in $C$. neglecta where the uptake was stimulated at an intermediate density.

The amphipods used in our study were $1 \mathrm{yr}$ old and densities were within the range of natural levels. In the field, amphipod densities can be twice as high when considering both year classes, i.e. juveniles and adults. Subsequently, the mechanical disturbance and burial of organic material could be even more pronounced in nature than shown in this experiment.

Acknowledgements. Many thanks to Nils Walberg for building the microcosm set-up, to Jan-Erik Hägerroth for assistance in the field, and to Lars-Åke Gisselsson for providing the algae. We also thank Anne Stockenberg who made valuable remarks on the manuscript. This research was supported by a Marie Curie postdoctoral fellowship to W.J.v.d.B. and the foundation of Lars Hierta. Ragnar Elmgren is thanked for financial support.

\section{LITERATURE CITED}

Aarnio K, Bonsdorff E, Norkko A (1998) Role of Halicryptus spinulosus (Priapulida) in structuring meiofauna and settling macrofauna. Mar Ecol Prog Ser 163:145-153

Alkemade R, Wielemaker A, Hemminga MA (1992) Stimulation of decomposition of Spartina anglica leaves by the bacterivorous marine nematode Diplolaimelloides bruciei (Monhysteridae). J Exp Mar Biol Ecol 159:267-278

Aller RC, Aller JY (1992) Meiofauna and solute transport in marine muds. Limnol Oceanogr 37(5):1018-1033

Alm G (1915) Monographie der Schwedischen SüsswasserOstracoden nebst systematischen Besprechungen der Tribus Podocopa. Zool Bidr Uppsala 4:1-247

Alongi DM (1985) Effect of physical disturbance on population dynamics and trophic interactions among microbes and meiofauna. J Mar Res 43:351-364

Alongi DM, Tenore KR (1985) Effect of detritus supply on trophic relationships within experimental benthic food webs. I. Meiofauna-polychaete (Capitella capitata (type I) Fabricius) interactions. J Exp Mar Biol Ecol 88:153-166

Ankar S, Elmgren R (1976) The benthic macro- and meiofauna of the Askö-Landsort area (northern Baltic proper). A stratified random sampling survey. Contrib Askö Lab Univ Stockholm 11:1-115

Blomqvist S, Larsson U (1994) Detrital bedrock elements as tracers of settling resuspended particulate matter in a coastal area of the Baltic Sea. Limnol Oceanogr 39:880-896

Blomqvist S, Lundgren L (1996) A benthic sled for sampling soft bottoms. Helgol Meeresunters 50:453-456

Coull BC, Palmer MA (1984) Field experimentation in meiofaunal ecology. Hydrobiologia 118:1-19

Creed EL, Coull BC (1984) Sand dollar, Mellita quinquiesperfortata (Leske), and sea pansy, Renilla reniformis (Cuvier) effects on meiofaunal abundance. J Exp Mar Biol Ecol 84: $224-234$

Cullen DJ (1973) Bioturbation in superficial marine sediments by interstitial meiobenthos. Nature 242:323-324 
Ejdung G, Elmgren R (1998) Predation on newly settled bivalves by deposit-feeding amphipods: a Baltic Sea case study. Mar Ecol Prog Ser 168:87-94

Elmgren R (1978) Structure and dynamics of Baltic benthos communities, with particular reference to the relationship between macro- and meiofauna. Kiel Meeresforsch 4:1-22

Elmgren R, Ankar S, Marteleur B, Ejdung G (1986) Adult interference with postlarvae in soft sediments: Pontoporeia-Macoma example. Ecology 67:827-836

Elofson O (1941) Zur Kenntnis der marinen Ostracoden Schwedens mit besonderer Berücksichtigung des Skageraks. Zool Bidr Uppsala 19:215-534

Fleeger JW, Shirley TC, McCall JN (1995) Fine-scale vertical profiles of meiofauna in muddy subtidal sediments. Can J Zool 73:1453-1460

Guillard RL (1975) Culture of phytoplankton for feeding marine invertebrates. In: Smith WL, Chanley MH (eds) Culture of marine invertebrate animals. Plenum Press, New York, p 29-60

Hartmann G (1994) The findings of Heterocyprideis sorbyana (Jones) in the Antarctic. (An example of bipolar distribution on species level). Mitt Hambg Zool Mus Inst 91:89-90

Heiskanen AS, Kononen K (1994) Sedimentation of vernal and late summer phytoplankton communities in the coastal Baltic Sea. Arch Hydrobiol 131:175-198

Henderson PA (1990) Freshwater ostracods. In: Kermack DM, Barnes RSK (eds) Synopsis of the British Fauna (New Series) 42. Universal Book Services, Oegstgeest, p 1-228

Hill C, Elmgren R (1987) Vertical distribution in the sediment in the co-occurring benthic amphipods Pontoporeia affinis and P. femorata. Oikos 49:221-229

Hill C, Quigley MA, Cavaletto JF, Gordon W (1992) Seasonal changes in lipid content and composition in the benthic amphipods Monoporeia affinis and Pontoporeia femorata. Limnol Oceanogr 37(6):1280-1289

Järvekülg A (1973) Distribution and ecology of local populations of benthic glacial relicts. Oikos (Suppl)15:91-97

Joint IR, Gee MJ, Warwick RM (1982) Determination of finescale vertical distribution of microbes and meiofauna in an intertidal sediment. Mar Biol 72:157-164

Kester DR, Duedall IW, Connors DN, Pytkovocz RM (1967) Preparation of artificial seawater. Limnol Oceanogr 12: 176-179

Kneib RT (1985) Predation and disturbance by grass shrimp, Palemonetes pugio Holtuis, in soft-substratum benthic invertebrate assemblages. J Exp Mar Biol Ecol 93:91-102

Kononen K, Nommann S, Hansen G, Hansen R, Breuel G, Gupalo E (1992) Spatial heterogeneity and dynamics of vernal phytoplankton species in the Baltic Sea in AprilMay 1986. J Plankton Res 14:107-125

Lopez G, Elmgren R (1989) Feeding depths and organic absorption for the deposit-feeding benthic amphipods Pontoporeia affinis and Pontoporeia femorata. Limnol Oceanogr 34:982-991

Modig H, Ólafsson E (1998) Responses of Baltic benthic invertebrates to hypoxic events. J Exp Mar Biol Ecol 229:133-148

Nehring S, Jensen P, Lorenzen S (1990) Tube-dwelling nema-

Editorial responsibility: Otto Kinne (Editor), Oldendorf/Luhe, Germany todes: tube construction and possible ecological effects on sediment-water interfaces. Mar Ecol Prog Ser 64:123-128

Ólafsson E, Elmgren R (1991) Effects of biological disturbance by benthic amphipods Monoporeia affinis on meiobenthic community structure: a laboratory approach. Mar Ecol Prog Ser 74:99-107

Ólafsson E, Elmgren R (1997) Seasonal dynamics of sublittoral meiobenthos in relation to phytoplankton sedimentation in the Baltic Sea. Estuar Coast Shelf Sci 45:149-164

Ólafsson E, Moore CG (1990) Control of meiobenthic abundance by macroepifauna in a subtidal muddy habitat. Mar Ecol Prog Ser 65:241-249

Ólafsson E, Moore CG, Bett BJ (1990) The impact of Melinna palmata Grube, a tube-building polychaete, on meiofaunal community structure in a soft-bottom subtidal habitat. Estuar Coast Shelf Sci 31:883-893

Ólafsson E, Elmgren R, Papakosta O (1993) Effects of the deposit-feeding benthic bivalve Macoma balthica on meiobenthos. Oecologia 93:457-462

Ólafsson EB, Peterson CH, Ambrose WG Jr (1994) Does recruitment limitation structure populations and communities of macro-invertebrates in marine soft sediments: the relative significance of pre- and post-settlement processes. Oceanogr Mar Biol Annu Rev 32:65-109

Ólafsson E, Modig H, van de Bund WJ (1999) Species specific uptake of radio-labelled phytodetritus by benthic meiofauna from the Baltic Sea. Mar Ecol Prog Ser 177:63-72

Palmer MA (1988) Epibenthic predators and marine meiofauna: separating predation, disturbance, and hydrodynamic effects. Ecology 69:1251-1259

Savolainen I, Valtonen T (1983) Ostracods of the north-eastern Bothnian Bay and population dynamics of the principal species. Aquilo Ser Zool 22:69-76

Schmitt RJ (1996) Exploitation competition in mobile grazers: trade-offs in use of a limited resource. Ecology 77(2): 408-425

Schratzberger M, Warwick RM (1998) Effects of physical disturbance on nematode communities in sand and mud: a microcosm experiment. Mar Biol 130:643-650

Sundelin B, Elmgren R (1991) Meiofauna of an experimental soft bottom ecosystem-effects of macrofauna and cadmium exposure. Mar Ecol Prog Ser 70:245-255

Thistle D (1980) The response of a harpacticoid copepod community to a small-scale natural disturbance. J Mar Res 38: 381-395

Warwick RM, Gee JM (1984) Community structure of estuarine meiobenthos. Mar Ecol Prog Ser 18:97-111

Warwick RM, Clarke KR, Gee JM (1990) The effect of disturbance by soldier crabs Mictyris platycheles $\mathrm{H}$. Milne Edwards on meiobenthic community structure. J Exp Mar Biol Ecol 135:19-33

Warwick RM, McEvoy AJ, Thrush SF (1997) The influence of Atrina zelandica Gray on meiobenthic nematode diversity and community structure. J Exp Mar Biol Ecol 214: 231-247

Wilson WH (1991) Competition and predation in marine softsediment communities. Annu Rev Ecol Syst 21:221-41

Submitted: July 28, 1999; Accepted: February 3, 2000

Proofs received from author(s): August 8, 2000 